Draft version of the article that appeared in Studies in Travel Writing 23:2 (2019), p. 175-187. https://doi.org/10.1080/13645145.2019.1698844

Please refer to the published version to make any references and citations.

\title{
Slow Travel Writing: Anik See's Saudade: the Possibilities of Place
}

Ella Mingazova

Department of English and American literature, University of Liège and University of Leuven, Belgium e.mingazova@uliege.be

\begin{abstract}
The Slow Travel movement encourages tourists to use slower modes of transport, to leave the beaten track, to meet locals and to learn some basics of the foreign language. All of these principles have been present in travel writing for almost two centuries. Despite the importance of slowness for the genre, little attention has been given to this subject in travel writing studies. The essay contends that the valorisation of slowness in travel writing is intertwined with some of its central features such as nostalgia, the experience of place and the traveller/tourist dichotomy. Slowness, the essay argues, shaped the genre as we know it today. The focus of the discussion is on Anik See's Saudade: the Possibilities of Place (2008), which echoes traditionally formulated ideas about the importance of slowness for travelling and relies on a contemporary understanding of slowness as a trope of resistance to the excesses of capitalism.
\end{abstract}

Keywords: Slow Travel, Nostalgia, Slowness, Speed, Place, Tourism

In the contemporary context of cultural acceleration, slowness benefits from an upsurge in popularity. Initiatives that resist the pervasiveness of speed in contemporary culture are known under the umbrella term "Slow Movement" after the publication of Carl Honoré's In Praise of Slowness in 2004. The most famous of these initiatives is the Slow Food movement, launched by Carlo Petrini in 1986 as a resistance to fast food. Since then, Honoré's criticism of speed has been extended to other cultural practices, and movements such as Slow Fashion, Slow Journalism and Slow Academia have been launched. Travel too has been rethought through the lens of slowness: the Slow Travel movement encourages tourists to use slower modes of transport, to leave the beaten track, to get to know locals, to learn some basics of the foreign language and to welcome unexpectedness. Although this movement started around 2000 and began to gain momentum in 2009 with the publication of “A Manifest for Slow Travel” by Nicky Gardner (Germann Molz 2009, 
277), the principles it promotes have been present in travel writing for almost two centuries. In fact, Slow Travel explicitly takes travel writing and the adventures of travel writers such as Robert Louis Stevenson, Théophile Gautier, Isabelle Eberhardt and Freya Stark as models to follow. Tellingly, one of the ambassadors of Slow Travel today is the travel writer Pico Iyer. In The Art of Stillness: Adventures in Going Nowhere, Iyer exposes the virtues of staying in one place in our age of mobility and connectedness. "I recall how, not so many years ago," he writes, "it was access to information and movement that seemed our greatest luxury; nowadays it's often freedom from information, the chance to sit still, that feels like the ultimate prize." $(2014,6)$

Despite the importance of slowness for the genre of travel writing, relatively little attention has been given to this subject in travel writing studies. Discussions of slowness in travel writing have so far mainly focused on the choice of slower modes of transport and in particular on pedestrianism (Coverley 2006; Genoni 2011; Gros 2014; Forsdick 2016). As put by Patrick Holland and Graham Huggan in Tourists with Typewriters:

Speed is antithetical to the physical and verbal meandering of conventional travel writing, which relies on modes of transportation (walking, cycling, rail travel) that require the passage of time. Speed also opposes the myth of labor on which travel writing so often depends. $(1998,23)$

This attention to modes of transport is indisputably important for, as pointed out by Tim Youngs, this choice affects the form of the narrative as different forms of travel offer to the traveller different perceptions and different engagements with landscape, culture and people $(2013,331)$. However, slowness in travel writing, I would like to argue, manifests a deeper criticism of the culture of speed, which shaped the genre as we know it today. I will contend that the valorisation of slowness in travel writing is strongly intertwined with some of the genre's central features, namely nostalgia, the experience of place and the traveller/tourist dichotomy.

I shall focus my discussion on Anik See's Saudade: the Possibilities of Place, published in 2008 by Coach House Books in Canada. This book explicitly addresses the value of slowness. "Slowness," See writes, "is a way to something beyond privilege. It is a way to grace" $(2008,176)$. A recent travelogue, it also reflects how slowness has gained a new significance in contemporary culture. In the Slow Movement, as already highlighted by Ursula Heise (2016), slowness is a master trope for initiatives that not only focus on temporal experiences but, more generally, seek to fight capitalism, inequality and climate change and to promote localism, sustainability, attention and mindful consumption. Saudade, I argue, echoes ideas about the importance of slowness for 
travelling that are traditionally formulated in travel writing but also relies on a contemporary understanding of slowness as a trope of resistance to the excesses of capitalism.

\section{Slowness and Nostalgia}

Anik See is a Canadian travel writer and translator based in The Netherlands. Saudade: the Possibilities of Place is her second book. While her first travelogue, A Fork in the Road: Tales of Food and Travel (Macmillan, 2000), is an account of her travels in Asia, the Middle East and Latin America, Saudade: the Possibilities of Place does not follow one specific journey. Organised thematically rather than by destination, its different chapters, ten in total, present the narrator, See's alter ego, with a different professional occupation each time. She is at times a supervisor in a camp, a book designer, a young woman on a journey through Australia with her friends, a journalist in Northern Canada and a cyclist in Amsterdam. At the end of the book, it becomes clear that the author, the narrator and the main character are one and the same person represented at different moments in her life, something that reflects how human identity is always in flux. Personal documents such as a telegram reporting on her mother's birth and a photograph of the narrator's grandmother serve to convey an impression of truthfulness to the events described. Saudade maintains the autobiographical pact between reader and writer, essential for the travelogue to be identified as such (Borm 2004, 17; Hulme and Youngs 2002, 6). Saudade belongs to the form of travel writing identified as postmodern by Alisson Russell (2000) or, in Justin D. Edwards and Rune Graulund's terminology, to "innovative travel writing" (2012). This type of travel writing raises crucial questions about the ways space, subjectivity and text interact, thereby challenging cultural, geographic, and textual boundaries and representations. In Alison Russell's definition, this type of writing also addresses "the ways we construct, use, and travel through the space of the world and the space of the text" $(2000,11)$. In Saudade, Anik See constructs a reflection on place and space on the basis of her travels. Her actual experiences of lands travelled (Sri Lanka, Australia, the Netherlands, Canada, the United States) are, however, secondary in the book since the interest of the narrator lies in the metaphorical and psychological aspects of space.

Saudade's fourth chapter, "Squeezing a Spiral into a Square Hole," does not deal with the subject of travel, and seems, at first sight, to disturb the book's coherence. The chapter is written in the form of a conversation on book design between the narrator and her friend, Walter. They talk about Robert Bringhurst's The Elements of Typographic Style and the right proportions for book design. The golden ratio, which is, as the narrator reminds us, the most pleasing proportion in the human body, musical scales or the text on a page, is discussed at length. The chapter calls attention to space as the primary material of a number of art forms, such as architecture and painting, and to how different representations of space interact. For instance, as her friend Walter explains, Piet 
Mondrian used the actual space of his studio as a preparation for his work, by painting lines on the walls and later transferring his perception of this actual space onto the space of the canvas (2008, 66). It is not movement through space but spatiality in its widest sense that lies at the heart of See's project. In addition to perceptions of place, landscape, mobility and borders, Saudade: the Possibilities of Place is a discussion of abstract spaces (of the mind, of the page, of the book, of the canvas). This concern is well illustrated by the book's cover. See, an experienced book designer, made decisions on the elements that surround the text, such as the overall design and the typesetting. The title of the book, "Saudade," printed on a map, extends over the borders of the page onto the book's spine and its flap. This design attracts the reader's attention to the composition of the page and to the materiality of the book. It invites the reader to look beyond the front cover, to the book's spine and to open its flap. The title "Saudade," printed in relief, is a Portuguese word that refers to a feeling of nostalgia defined in the book as "the feeling of yearning for something impossible to regain because it never quite existed" (See 2008, 171). It stands out from the paper's surface as if to emphasise the meaning of the title, the wish for presence in absence.

The Portuguese word "saudade" is said to have no direct equivalent in other languages. In The Future of Nostalgia, Svetlana Boym traces to the Romantic period the emergence of untranslatable words to refer to nostalgia in different national traditions. Boym gives examples such as Russian “toska," Czech "litost," German 'Heimweh" and French "mal du pays" (2001, 13). As is especially clear from the last two examples, these words are synonymous, not with the current understanding of nostalgia as a longing for a different time, but with the original meaning of nostalgia, a term coined in 1688 by Johannes Hofer as the medical equivalent for the emotion of homesickness (nostos — homecoming and algia - longing) (Starobinski and Kemp 1966, 85). Unlike today's most current understanding of nostalgia as a mental state for which no simple remedy can be provided, nostalgia in its original meaning was a medical condition that could be cured by returning to the place the patient longed for. See's narrator associates her saudade with homesickness and yearns for a particular type of place:

My saudade has no one image of physical geography or place that will provide all of those things that I want and need [...], but it is a composite of a number of places where I've experienced significant moments of realization [...]. I suspect the one I'll settle on in my imagination (since, by definition, I'll never have it) will be in Canada because it is home. $(2008,187-188)$

She does not yearn for her geographical home in Canada. It is its vastness of space that she misses, something the Netherlands, her adoptive country, cannot offer. Throughout the book, the narrator 
regularly contrasts Canada's vast lands with Europe's densely populated territories. She tries to cure herself by reading books thaat describe the landscapes for which she longs: "I've been reading a lot of Jim Harrison lately to allay the kind of homesickness that tends to set in after a year or so in a densely populated place — a homesickness not for a specific place, but merely for a wide open space" (See 2008, 76).

For expatriates, longing for home frequently implies a yearning for an idealised past. Nostalgia has been identified as a pervasive feature of travel writing, as demonstrated, for instance, by Ali Behdad (1994) and Patrick Holland and Graham Huggan (1998; 2004). Holland and Huggan identify two main kinds of nostalgia in contemporary travel writing: a yearning for the imperial order, for the Empire itself, on the one hand, and an "imperialist nostalgia" on the other. Coined by Renato Rosaldo, "imperialist nostalgia" refers to the paradoxical yearning of the agents of colonialism for "the very forms of life they intentionally altered or destroyed" in the process of colonisation $(1989,69)$. According to Holland and Huggan, this kind of nostalgia is present in contemporary travel writing in the yearning for a "simpler" past, a "simpler" way of life, often rural, premodern, and preindustrial $(2004,29)$. While explicit longing for Empire is absent from See's Saudade, its narrator's nostalgia is for the simple life in the countryside. ${ }^{1}$ She yearns to recover the unlit and unplumbed one-room cabin in the Canadian countryside from her childhood:

It was a one-room cabin where we had to melt snow for water in winter, where the hiss of a Coleman lantern was the only sound after the sun went down and dinner was cleared away. That and the crack of Scrabble tiles or the slow turning of pages on the books in four different sets of hands. $(2008,154)$

Keen to obliterate the gap between culture and nature, the narrator expresses a longing for authenticity, for presence and for unmediated experience, characteristic of the nostalgic mode. Nostalgia, Svetlana Boym writes, is "a yearning for a different time - the time of our childhood, the slower rhythm of our dreams" (2001, XV). Saudade's narrator explicitly expresses her preference for slowness over speed. For her, slowness has the virtue of offering an unmediated experience, to reconnect with oneself, with others and with nature. As do most travellers, she prefers slower modes of transport such as travelling by train instead of by plane or, better still, biking and walking, because they offer more freedom and more contact with the environment. Her preference for slower technologies, however, is not limited to technologies of transportation:

Call me old-fashioned, but I like the texture of slowness. How it lacks invasiveness. The repertory theatre once a month instead of a DVD and on-demand television every night. The typewriter instead of email. Letterpress printing instead of digital typesetting. The 
train instead of the plane, the bicycle not the car. The Coleman lantern or candles instead of the energy-efficient halogen lamp. (See 2008, 175)

See's narrator associates past technologies with slowness. As highlighted by Stephen Kern, every accelerating technology has a double effect: it speeds up the present and transforms the past into something slow $(2003,129)$. Slowness, therefore, plays an important role in nostalgia since slowness becomes associated with the past, a past to which we often want to return when we are overwhelmed by speed. In the current context of cultural acceleration, nostalgia functions as a defence mechanism that helps challenge the perceived superficiality and the loss of memory brought about by speed:

What we learn now becomes obsolete so fast that any connection with it is splintered back on, to incorporate the change into. What we learn now lacks a mythology. Or, at least, the mythology has a Teflon-like quality. (See 2008, 168)

In cultural studies, a similar hypothesis has been formulated by Andreas Huyssen, who identifies the contemporary obsession with memory and archiving as a response to cultural acceleration (2000). In fact, the preference of slowness over speed and its rediscovery in travel writing from the nineteenth century on can be analysed as a nostalgic response to acceleration.

At the end of the nineteenth century, the age of empire reached its height and the age of exploration attained its geographical limit. 1890 marks the end of the Frontier in the United States; Asia and Africa were divided between the most powerful world powers around this time; and the last "unexplored" spaces, the North and the South Pole, were reached in 1909 and in 1911 respectively (Kern 2003, 164, 166). There were no more territories left to be explored. Enda Duffy (2009) argues that this realisation shattered the way space was perceived, which in turn brought about a new phenomenon, speed, made possible by technological innovations. For Duffy, it is above all the car that offered an experience of speed to the masses. Instead of a passive experience of speed such as the one given by the train, the car allowed an expression of personal power and " $[\mathrm{b}] \mathrm{y}$ the twenties, the new heroes were more likely to be race car drivers or adventurers who endured massive hardship to break some record of endurance, rather than colonial explorers" (Duffy 2009, 8). The time of the explorers was definitely over. However, travel writers of the time, privileged as they were, continued to cultivate the illusion and the ideals of exploration. They began to actively seek spaces untouched by modernity to escape from their home culture, which was experiencing rapid modernisation and acceleration. Interestingly, while at the beginning of the twentieth century, in literature and the arts, the tendency was to experiment with the possibilities of the different media 
to convey this experience of speed, travel writing was more inclined to capture slowness. In order to do this, travel writers felt the need to retreat to specific, slower, locations. This necessity remains present in today's travel writing. As Debbie Lisle points out, "travel writers do not choose their destinations simply because the landscape is different, or because it is located on the other side of the world, they choose destinations that will allow them to go back in time as well as far away" (2006, 204 her emphasis). Travel writers' search for slower locations, it would seem, determines not only how but also where they travel.

\section{Slowness and Place}

The difference between the concepts of space and place is well known in travel writing studies. Space, abstract and indefinite, allows movement or travel; place is a definite location. The powerful influence of place, rather than space, on human identity has been termed by anthropologist Liisa Malkki “a sedentarist metaphysics" (1992). Following Deleuze and Guattari, Malkki points out that a sedentarist metaphysics is anchored in language through the imagery of naturalising and botanical terms: for example, we often think of the nation as nourished by the soil in which it is rooted and the genealogy of an individual is represented as arborescent in form by a family tree (1992, 27-28). Malkki also highlights that people often derive their identity from their rootedness in place and refer to their nation with words evoking blood ties, such as "the motherland" or "the fatherland." Expanding on Malkki's terminology, human geographer Tim Cresswell opposes two metaphysical ways of viewing the world: a sedentarist metaphysics and a nomadic metaphysics (2006). While a sedentarist metaphysics considers rootedness as a fundamental need of human nature and insists on the influence of place on the human subject, a nomadic metaphysics values mobility and flux in space and associates place with confinement. These are of course two ends of a spectrum rather than neatly separated constructs. It is impossible to think of mobility only in terms of a sedentarist or a nomadic metaphysics, as displacement always implies rootedness and vice versa. However, despite the increased mobility of people in recent decades, sedentarism remains more deeply entrenched in our thought. Elsa Triolet reflecting on her condition of immigrant, for instance, argues that humans do or do not achieve "successful acclimatisation" in a certain environment, just like plants and animals (quoted in Kaplan 1996, 33). The significance of place on human identity is omnipresent in contemporary literature and politics.

A figure of restlessness, in need of movement, the travel writer, epitomised by Bruce Chatwin, is often described as a modern nomad. Travel writing is often thought to be promoting a nomadic aesthetics and, in Caren Kaplan's words, "participat[ing] in mythologized narrativizations of displacement" $(1996,2)$. In her article on discriminations towards immigrants and Gypsies, 
Malkki shows how, influenced by a sedentarist metaphysics, we tend to consider mobility as a threat and a disruption to societal order (1992). This threat justifies the existence of strict immigration laws that regulate people's movements. For instance, when travelling from Canada by car, Saudade's narrator is denied entry to the United States because she is said to "lack ties to Canada" $(2008,127)$. It is her apparent lack of roots in a place, which border officials judge from the numerous visas in her passport, and from the absence of material possessions (no house, no car), that prevent her from entering the country. Yet, it seems that a sedentarist metaphysics prevails in the genre. The subject of travel writing is rarely space, or as Bill Ashcroft puts it, "travel writing is seldom about travel itself; it is about place" $(2009,229)$.

As the reference to place in its subtitle suggests, a sedentarist metaphysics strongly predominates in Saudade: the Possibilities of Place. The book opens with an epigraph from Ryszard Kapuściński's The Cobra's Heart, which articulates the idea that identities are determined by location:

And finally, the most important discovery - the people. The locals. How they fit this landscape, this light, these smells. How they are as one with them. How man and environment are bound in an indissoluble, complementary, and harmonious whole. I am struck by how firmly each race is grounded in the terrain in which it lives, in its climate. We shape our landscape, and it, in turn, moulds our physiognomy. (quoted in See 2008, 15)

Kapuściński's observation is based on the assumption that there is an organic link between humans and their environment. Roots and family are the central theme of the chapter "Rainy Summit," which deals with the death of the narrator's grandmother and with family bonds. She discovers that her grandmother as a young woman living in Nazi Germany — at a time when knowing one's roots was a question of life and death - cycled around Europe to put together her family tree. In the chapter entitled "Symbols of Infinity," she compares her experiences in Yellowknife, in Northern Canada, where tourists can learn about traditional lifestyle and crafts, such as caribou tufting, moccasin making and embroidery, to the smoke tree. While roots, paramount to the tree's existence, are usually invisible because hidden in the soil, the smoke tree's peculiar branch system mirrors its roots system, thereby making it visible. Similarly, Yellowknife's present mirrors its past:

Right then, when Janes showed me those caribou skins, swishing through the stench of beaver flesh; when I stood on the edge of the escarpment and saw those buffalo glide across the plain; on the plain flying over Great Slave Lake and standing in a sea of driftwood a few hours later, I felt like I was looking at a cross-section of a smoke tree - 
suspended between history and possibility, between definition and evolution. I felt housed between reflections, and I understood why we need and how we are defined not merely by places of strange and isolated beauty but by the distance between them, whether they are pinpoints or unending ribbons. (See 2008, 122)

Human geographer Yi-Fu Tuan theorises the opposition between space and place in temporal terms: "if we think of space as that which allows movement, then place is pause; each pause in movement makes it possible for location to be transformed into place" $(1977,6)$. In other words, the experience of place requires slowing down. Travel writers, therefore, often choose slower modes of transport such as walking or biking, which offer a slower, sensual experience of place. Dervla Murphy, for instance, wrote that she cannot say that she has been to a place unless she has used a non-motorised means of transportation $(1992,124)$, and Iain Sinclair's explorations of London result from his conviction that you do not know a place unless you've traversed it on foot (1997). In John Urry's terms, travel writers look for an experience of the land, rather than the landscape. Landscape, on the one hand, is a two-dimensional experience, which relies on the sense of sight. It can be perceived when passing through a place in faster modes of transport, through the window of a car or train. The land, on the other hand, is "a physical, tangible resource to be ploughed, sown, gazed and built upon, a place of functional work", which requires remaining in place and offers a three-dimensional experience that is perceived through all the senses (Urry 2007, 102). Of course, alternative conceptions of travel writing that chronicle movement through space rather than the experience of place do exist. The narrators of Jack Kerouac's fictionalised travelogues, On the Road (1951) and Dharma Bums (1958), Jean Baudrillard's America (1981), Jonathan Raban's Passage to Juneau (1999) and François Bon's Paysage Fer (2014) essentially seek to be on the road, in movement. They privilege speed over slowness, by choosing the car, the boat and the train as their modes of transport. However, most travel writers still prefer modes of transport that allow them to experience place through all of their senses at a leisurely pace.

The origin of the traveller/tourist distinction in travel writing coincides with the shift in preference for a slow experience of place and the use of slower modes of transport. The word "tourist," which was originally reserved to designate privileged young men from the European elite on their Grand Tour, took on a pejorative meaning in the nineteenth century, as a consequence of the modernisation and the democratisation of travel. In his study of the emergence of the traveller/tourist dichotomy James Buzard remarks that "the voices raised against 'mere tourism' [are] often those raised also against the spread of technology and machinery" $(1993,32)$. Travellers rejected technological innovations, especially in transportation, because they were said to ruin the adventurous character of travel. Relying on the etymological origin of "travel" from "travail" 
("labour"), travel writers argued that travelling well is a task that requires effort and courage. Travel writers became nostalgic about older modes of transport, associating its modern modes with 'mere' tourists. In the age of the horse-drawn carriage, travellers felt nostalgic about walking; in the age of the railway, travellers lamented the loss of the horse-drawn carriage (Buzard 1993, 37). They held that tourists could not properly experience place because they travelled to and through their destinations too fast. While travellers sought to gain in-depth knowledge of places, of the land, tourists looked at the landscape and remained on the surface. Slowness served and continues to serve as a criterion of differentiation between tourism and a "morally superior" form of travel - a dichotomy on which the genre still relies. Speed became associated with superficiality and slowness with depth in travel writing. Heat-Moon's PrairyErth: Deep Map is one example from contemporary travel writing that pushes this principle to its extreme. In the book, the narrator opposes "two-dimensional Rand McNally travellers" to "travellers who perceive a place as part of a deep landscape in slow rotation at the center of a sphere" $(1991,246)$. He himself prefers slowness to the point of not moving at all, which, as the title of the book suggests, allows him to pay deep attention to one place, located in Chase County, Kansas. ${ }^{2}$

A sedentarist metaphysics binds a place with a particular culture. The experience of a particular culture is precisely what pushes travellers' choice of location. Binding a place with a culture, anthropologists Akhil Gupta and James Ferguson remark, necessarily entails "the self" and "the other" difference (1997), or what in travel writing studies is known as the process of "othering." In a sedentarist metaphysics, movements of people are believed to alter the set of predetermined cultural values particular to a place (Cresswell 2006, 33). Travel writers' particular attention to places and their cultural distinctiveness pushes them to consider other fellow travellers (or tourists) as spoiling the illusion of complete cultural isolation and to declare the end of travel in the age of tourism. Ideas formulated against tourism in the nineteenth century are still persistent today. Debbie Lisle argues that the traveller/tourist dichotomy is a manifestation of revived colonialism and the process of othering in contemporary travel writing. Instead of the "colonised savage," modern travel writers produce an "other" from their own culture in the form of the tourist, whose ubiquitous presence impedes them from the great pleasures of "discovery" of new lands (Lisle 2006, 77).

A progressive dissolution of the distinction between traveller and tourist has been observed in contemporary travel writing as a possible effect of the disintegration of dichotomies under the influence of postmodernism. Instead, in postmodern travel writing, the dichotomy has morphed into "post-tourist playfulness," which is a "recognition that the writer-traveller cannot evade either his or her tourist role" (Russell 2000, 10). However, as observed by Patrick Holland and Graham 
Huggan $(1998,208)$ and by Catherine Mee $(2014,22)$, although it is true that many travel writers more readily admit that they too are tourists than in the past, the traveller/tourist dichotomy has not disappeared from contemporary travel writing but simply become more subtle. Saudade is one case in point. Explicit expressions of annoyance with tourists are mostly absent from the book and the narrator actually refers to herself as a "Western tourist." Yet despite its apparent disappearance, the traveller/tourist distinction subtly persists when the narrator observes tour buses invade the Rocky Mountains and formulates the common argument that tourists are unable to leave the beaten track (See 2008, 182). It seems that discussions of travel writing and the traveller/tourist dichotomy should not only consider nostalgia for a colonial past but also a sedentarist metaphysics and the prevalence of slowness in the genre.

\section{The Privilege of Slowness}

Outside of travel writing, it is speed that is traditionally valued in travel: those who can travel quickly and avoid wasting their time are those who have the financial means to buy private jets or, more commonly, to own a car instead of a bike. However, at the other end of the spectrum, slowness can also be a privilege. In her social anthropological work on Slow Movements, Sarah Sharma (2014) has emphasised that the valorisation of slowness often depends on unacknowledged class privileges. The German theorist of acceleration Harmut Rosa remarks that while time pressure is traditionally given social approval, because signifying higher competences and thus desirability and productivity, slowness might be turning into a marker of social distinction in late modernity, creating a new class of people that have the financial means to "go slow" $(2013,135)$. One could argue that the existence of the modern travelogue has been relying on such people since the nineteenth century.

As observed by Barbara Korte (2008), in the time of colonial exploration and discovery, slowness in travel writing was generally associated with stagnation and a lack of efficiency. However, from the second half of the nineteenth century, when railway travel and tourism became much more affordable to the masses, slowness gained approval from British travel writers. Mass tourism developed in the context of an establishing capitalist society that increasingly valued punctuality and an efficient use of time. Middle class tourists (and later those from the working class) had relatively short periods available away from work and had to respect schedules imposed on them by the use of public modes of transport, for instance, or those of the guided tour (Dann 1999, 168). Travellers, usually from upper classes, could afford to avoid this strict temporal organisation imposed on tourists: they strongly opposed it, and, when possible, refused to use public modes of transport. They stayed longer to get a 
better sense of place and to learn the language of the region they visited. Numerous travelogues, such as Alexander Kinglake's Eothen (1844) and Robert Louis Stevenson's An Inland Voyage (1878) and Travels with a Donkey (1879), focusing on deliberately slow and unscheduled forms of travel were written in that period (Korte 2008, 44). This shift has contributed to transforming the genre, as it coincides with its gradual change from predominantly impersonal accounts of discovered lands during the colonial era to the most personal account of a journey, which resulted in travel writing in the modern sense, closer to a personal memoir rather than a report. ${ }^{3}$ The pleasure of being outside of social time and inside the slower rhythm of travel has become a recurrent theme in travel writing. In Arabian Sands, for instance, Wilfred Thesiger appreciates the slowness of his travels through the desert because it gives him "time to notice things" ([1959] 2007, 60). In a different vein, Patrick Mayle's A Year in Provence (1989) depicts the unhurried rhythms of the French countryside and opens with remarks on customary never-ending dinners.

Saudade's narrator is aware that slowness is a luxury. She compares her experience to that of her grandmother, who, as a young woman, had to cycle around Europe because she could not afford a car (2008: 46). Unlike her, the narrator deliberately chooses the bike as her mode of transport and comments that her wish to live in simplicity comes from her having the benefit of choice. She contrasts her parents' unlit and unplumbed cabin in Canada to the situation in the capital of the Republic of Georgia, Tbilisi, in the nineties:

There, water and electricity were simultaneously a privilege and a necessity. There is a way to survive without regular access to convenience, but when one actively chooses to go without it, the choice creates an undeniable charm (mostly because one can decide to renege when the reality and consequences of that choice become too difficult to manage). When one simply has to live without it, is forced to, there is no charm. [...] It's here, after seeing the woman who owns the room you - a Western tourist in Tbilisi are staying in walk across a field to a square and line up to fill the bottles and pails of water you consumed that you realize that choice is privilege. Choice is freedom, and neither privilege nor freedom is a right or an entitlement. It's here, as you run down the stairs of the building you're staying in and across the field to help the woman replenish and bring back the water you took, that you realize how despicable we the chosen privileged are, and you ask yourself exactly how is it that we have become this way? And why do we refuse to change? (See 2008, 157-58, her emphasis)

The narrator's yearning for simplicity is motivated by this guilt at financial privilege. Slowness for her is "an instinctual need for honest, self-sufficient living. And penance. For 
being so lucky" (See 2008, 163). More than a nostalgic reminiscence, her parents' cabin and its slower rhythm function as an ideal for the simple lifestyle she wishes to lead. Her urge to slow down is explicitly linked to more responsible consumer behaviour. Her wish for slowness, paradoxically enough, is motivated by the guilt at her financial privilege but relies on this very privilege to exist.

The creation of the dichotomy of slowness versus speed inevitably leads to differentiation or othering. Saudade's narrator explains that during her travel in Cuba before Castro's death, appliances such as hairdryers, dishwashers, microwaves and televisions, were very difficult to afford but were present even in the poorest homes. She finds it difficult to "understand how so much want could justify the spending of one's entire income on appliances that, in [her] opinion, one can largely live without" $(2008,160)$. Even if the narrator does not depict an exotic "other" in the traditional sense in her travel accounts, the figure of the different, arguably inferior "other" persists in the form of the consumerist, who from now on can be from any country. However, the valorisation of slowness in Saudade is not primarily a strategy of othering. The example above is the only time in the book this kind of othering occurs. Instead, slowness in Saudade is seen as a modest attempt to reflect and to reduce the social inequalities on which othering in travel writing traditionally relies.

Slowness, she writes, gives “time to replace what's being consumed, and to consider the significance of consumption" (See 2008, 177). Saudade's narrator recognises the value of speed but argues that slowness allows the reflection and critical thinking we often lack. She invites the reader to reflect on distance, on slowness and on speed by sitting in an airport in order " $[t]$ o see the collision between waiting and the force of the philosophy of speed, of the plane. All that waiting, only to get somewhere faster" $(2008,186)$. Her wish for a life in simplicity and for slowness are not merely motivated by a nostalgia for a better past. She advocates for minimalism and slowness as a possible means of social change, for a better future, and at least, as she writes in the book's last words: "It's a kind of future" $(2008,189)$.

\section{Conclusion}

In this article, I have focused on slowness in Saudade: the Possibilities of Place by Anik See for two reasons. First, this analysis allowed me to foreground the significance of slowness in travel writing since the second half of the nineteenth century. Slow travel, a contemporary movement that promotes an alternative way of travelling, takes its inspiration from a long-standing and often overlooked tradition in travel writing. I have tried to show how slowness is an essential aspect of some of the genre's central features, namely nostalgia, the experience of place and the 
traveller/tourist dichotomy. The valorisation of slowness in travel writing often occurs as a nostalgic response to acceleration. Overwhelmed by speed at home, travel writers seek places for their travels that allow them to return to a slower past and perpetuate the illusion of travel as exploration rather than as tourism. Preferring to travel at an unhurried pace, travellers usually prefer slower modes of transport that allow them to take their time to experience places and their distinctive culture, thereby nurturing the view that a place and its people are intrinsically and organically linked.

Second, analysing a contemporary travelogue allows me to address the trope of slowness as a criticism of contemporary speed. As already highlighted by David Harvey, the acceleration in the pace of consumption, which the Western world has been experiencing from the second half of the twentieth century, goes hand in hand with ephemerality and instantaneity and with the increased production of waste $(1989,285-286)$. Contemporary valorisations of slowness and initiatives like the Slow Movement seek to resist this tendency. A sort of Slow Movement avant la lettre, travel writing, it seems to me, constitutes a rich field of research for those interested in the recent valorisation of slowness in the humanities.

${ }^{1}$ In The Country and The City, Raymond Williams has shown how the country, in contrast to the city, acts as a symbol of "old ways, human ways, natural ways." The country, Williams also argues, is often associated with an idea of childhood, "of delighted absorption in our own world, from which, eventually, in the course of growing up, we are distanced and separated" (1973, 297).

${ }^{2}$ It should be noted that the association of slowness with depth is not limited to travel writing. It is also present in the concept of close reading, which is a slow process that seeks to attain an in-depth knowledge of the text. For an analysis of PrairyErth, see Hulme (2009).

${ }^{3}$ On this shift in travel writing from the impersonal to the personal account of a journey, see, for instance, Casey Blanton in Travel Writing: The Self and The World (2002). 


\section{References}

Ashcroft, Bill. 2009. “Afterword.” In Travel Writing, Form, and Empire: The Poetics and Politics of Mobility, edited by Julia Kuehn and Paul Smethurst, 229 - 241. New York: Routledge.

Behdad, Ali. 1994. Belated Travelers: Orientalism in the Age of Colonial Dissolution. Durham, N.C: Duke University Press.

Blanton, Casey. 2002. Travel Writing: The Self and The World. New York: Routledge.

Borm, Jan. 2004. “Defining Travel: On the Travel Book, Travel Writing and Terminology.” In

Perspectives on Travel Writing, edited by Glenn Hooper and Tim Youngs, 13 - 26.

Aldershot, Hants, England ; Burlington, VT: Ashgate.

Boym, Svetlana. 2001. The Future of Nostalgia. New York: Basic Books.

Buzard, James. 1993. The Beaten Track: European Tourism, Literature, and the Ways to Culture, 1800 - 1918. Oxford: Clarendon Press.

Coverley, Merlin. 2006. Psychogeography. Harpenden: Pocket Essentials.

Cresswell, Tim. 2006. On the Move: Mobility in the Modern Western World. New York: Routledge.

Dann, Graham. 1999. "Writing out the Tourist in Space and Time." Annals of Tourism Research 26

(1): 159 - 87. https://doi.org/10.1016/S0160-7383(98)00076-0.

Duffy, Enda. 2009. The Speed Handbook: Velocity, Pleasure, Modernism. Durham, NC: Duke University Press.

Edwards, Justin D, and Rune Graulund. 2012. Mobility at Large: Globalization, Textuality and Innovative Travel Writing. Liverpool: Liverpool University Press.

Forsdick, Charles. 2016. "Travel and the Body: Corporeality, Speed and Technology." In The Routledge Companion to Travel Writing, edited by Carl Thompson, 68-77. New York: Routledge.

Genoni, Paul. 2011. “The Pilgrim's Progress across Time: Medievalism and Modernity on the Road to Santiago." Studies in Travel Writing 15 (2): 157 - 75.

https://doi.org/10.1080/13645145.2011.565580.

Germann Molz, Jennie. 2009. "Representing Pace in Tourism Mobilities: Staycations, Slow Travel and The Amazing Race.” Journal of Tourism and Cultural Change 7 (4): 270 - 286. https://doi.org/10.1080/14766820903464242.

Gros, Frédéric. 2014. A Philosophy of Walking. London: Verso.

Gupta, Akhil, and James Ferguson. 1997. “Culture, Power, Place: Ethnography at the End of an Era.” In Culture, Power, Place: Explorations in Critical Anthropology, edited by Akhil Gupta and James Ferguson, 1 - 32. Durham, NC: Duke University Press.

Harvey, David. 1989. The Condition of Postmodernity: An Enquiry into the Origins of Cultural Change. Cambridge, Mass.: Blackwell.

Heat Moon, William Least. 1991. PrairyErth: A Deep Map. Boston, Massachusetts: Houghton Mifflin Company.

Heise, Ursula K. 2016. "Slow-Forward to the Future." In Postmodern/Postwar and after:

Rethinking American Literature, edited by Jason Gladstone, Andrew Hoberek, and Daniel Worden, 251 - 259. Iowa City: University of Iowa Press.

Holland, Patrick, and Graham Huggan. 1998. Tourists with Typewriters: Critical Reflections on Contemporary Travel Writing. Ann Arbor: University of Michigan Press. 
Holland, Patrick, and Graham Huggan. 2004. "Varieties of Nostalgia in Contemporary Travel

Writing." In Perspectives on Travel Writing, edited by Glenn Hooper and Tim Youngs, 140151. Aldershot, Hants, England ; Burlington, Vt., USA: Ashgate.

Hulme, Peter, and Tim Youngs. 2002. “Introduction.” In The Cambridge Companion to Travel

Writing, edited by Peter Hulme and Tim Youngs, 1 - 14. Cambridge: Cambridge University Press.

Hulme, Peter. 2009. “Deep Maps: Travelling on the Spot.” In Travel Writing, Form, and Empire: The

Poetics and Politics of Mobility, edited by Julia Kuehn and Paul Smethurst, 132 - 147. New York: Routledge.

Huyssen, Andreas. 2000. “Present Pasts: Media, Politics, Amnesia.” Public Culture 12 (1): 21 - 38.

Iyer, Pico. 2014. The Art of Stillness: Adventures in Going Nowhere. New York: TED Books/Simon $\&$ Schuster.

Kaplan, Caren. 1996. Questions of Travel: Postmodern Discourses of Displacement. Post-

Contemporary Interventions. Durham, N.C: Duke University Press.

Kern, Stephen. 2003. The Culture of Time and Space, 1880-1918: With a New Preface. Cambridge, Mass: Harvard University Press.

Korte, Barbara. 2008. “Chrono-Types: Notes on Forms of Time in the Travelogue.” In Writing

Travel: The Poetics and Politics of the Modern Journey, edited by John Zilcosky, 25 - 53.

Toronto: University of Toronto Press.

Lisle, Debbie. 2006. “The Global Politics of Contemporary Travel Writing.” Cambridge University Press.

Malkki, Liisa. 1992. "National Geographic: The Rooting of Peoples and the Territorialization of

National Identity among Scholars and Refugees." Cultural Anthropology 7 (1): 24 - 44.

Mee, Catharine. 2014. Interpersonal Encounters in Contemporary Travel Writing: French and Italian Perspectives. http://site.ebrary.com/id/10842750.

Murphy, Dervla. 1992. “Foot Notes: Reflections on Travel Writing.” The Wilson Quarterly (1976-)

$16(3): 122-29$.

Rosa, Hartmut. 2013. Social Acceleration: A New Theory of Modernity. Translated by Jonathan Trejo-Mathys. New York: Columbia University Press.

Rosaldo, Renato. 1989. Culture \& Truth: The Remaking of Social Analysis: With a New Introduction. Boston: Beacon Press.

Russell, Alison. 2000. Crossing Boundaries: Postmodern Travel Literature. New York: Palgrave/St. Martin's Press.

See, Anik. 2008. Saudade: The Possibilities of Place. 1st ed. Toronto: Coach House Books.

Sharma, Sarah. 2014. In the Meantime: Temporality and Cultural Politics. Durham: Duke Univ. Press.

Sinclair, Iain. 1997. Lights out for the Territory: 9 Excursions in the Secret History of London. London: Granta Books.

Starobinski, Jean, and William S. Kemp. 1966. “The Idea of Nostalgia.” Diogenes 14 (54): 81 103. https://doi.org/10.1177/039219216601405405.

Thesiger, Wilfred. (1959) 2007. Arabian Sands. London: Penguin.

Tuan, Yi-fu. 1977. Space and Place: The Perspective of Experience. Minneapolis: University of Minnesota Press. 
Urry, John. 2007. Mobilities. Reprint. Cambridge: Polity Press.

Williams, Raymond. 1973. The Country and the City. Hogarth Critics. London: Hogarth Press.

Youngs, Tim. 2013. “Introduction.” Studies in Travel Writing 17 (4): 331 - 34.

https://doi.org/10.1080/13645145.2013.871777. 